\title{
Model Development of Integrated Entrepreneurship Learning with Based Internet/Intranet Learning Management System Applied at Malang State Polytechnic
}

\author{
Dr. Mohammad Maskan, M.Si., Ahmad Fauzi, S.Kom., M.MT \\ Drs. Ludfi Djajanto, MBA
}

\begin{abstract}
This study focused on development learning of the Entrepreneurship learning model at Malang State Polytechnic into learning model characterized by intranet/internet aided, which is Learning Management System (LMS) based Entrepreneurship learning model, in which this learning model employs students who are active, multi methods of teaching, and multi source of learning. Findings show that the product of Learning Management Sustem (LMS) based Entrepreneurship learning model is good. It means that product of Learning Management System based Entrepreneurship learning model is valid to use in the learning process of Entrepreneurship lesson at all department of Malang State Polytechnic. It is recommended that (1) teachers who are teaching lesson of Entrepreneurship should be given provision about Learning Management System based Entrepreneurship learning model, (2) For further development, this Entrepreneurship learning model can be in the form of Web Modular based on internet (3) To validate this Entrepreneurship learning model, it can be applied in other lessons and (4) For organizing Web Modular learning of all lesson material have developed by computer aided, likely: e-book, e-module and e-tutorial, so Malang State Polytechnic should be build e-library in future.
\end{abstract}

Keywords: developing learning model, entrepreneurship, learning management system-based learning model, e-learning.

\section{INTRODUCTION}

\subsection{Background}

Entrepreneurship learning approach existing up to now tend to teacher centered learning (CTL), where is only lecturer once sources in the learning, while student is learning object. Weakness of this approach is student only receive what lecture learned and passive attitude, competence of entrepreneurship learning material among lecturers diference because education background not only from management program and learning material mostly textual and learning methods are clasical approah, use intenet/intranet not yet so there is no strandatization of learning in State Polytechnic of Malang. Besides, student's motivation view on learning method that only listening, student only reach $30 \%$ from material what lecturer have learned so student's soft skill low and boring.

In the global era recently, learning model like that not fairly again because media and learning resources are many more and variety likely used learning environment and technology progress. The learning approach recently to take student as subject, so more student learn activeky, because student construct self knowledge in the learning process. For this, student centered learning more suitable with situation and timing recently. In the student centered learning model, lecturer role as motivator, mediator and facilitator in student's learning process. In other word, lecturer not only once sources of learning and learning process must no in the class room, but student can study from many learning sources likely: literature book, business man, business expert, internet, mass media (newspaper, research journal, paper), electronic media (television, radio, film) or business environment that around student lived. In the case, this learning process, student more actively, cooperative, participatise, reactive and pleasantly. Besides, student's learning evaluation more completely and concist are cognitive, affective and psicomotoric.

Integration of information and communication technology in the learning process have change learning methodology between lecturer and student. Recently, there is challange for State Polytechnic of Malang to facilitate to learning process can be held anywhere and anytime. Other requirement is there is mobile learning and student can access material learning from outside area. Information technological and telecommunication progress likely internet/intranet progress can be reachable. 
To answer this challange, so we develope learning model of entrepreneurship with learning management system based for State Polytechnic of Malang's student.

\subsection{Problem Research}

How is the learning model development process of learning management system based Entrepreneurship Subject with internet/intranet aided at State Polytechnic of Malang?

\section{THEORIES REVIEW}

\subsection{The Previous Studies on the Learning Model Development}

Banathy (1987) states that the criteria of the learning material development: (1) helps learners prepare an independent learning, (2) contains a comprehensive learning activity plan and enables a maximum response, (3) consists of a comprehensive learning content allowing to provide a learning opportunity to learners, (4) monitors all learning activities, and (5) provides feedback information to measure the learner's progress.

The learning development of the Entrepreneurship applies Dick \& Carey's with the following considerations:

a. This model applies nine systematic and comprehensive steps, allowing to provide detailed guidance to the level of learning material production.

b. This model has a programmed learning format, so that it can be used for personal learning need.

c. The adoption of this model is based on the idea that the lecturer's duty is as the learning planner, implementer, and evaluator.

d. This model refers to the system theory proven to succeed in military, industry and education.

e. This model can be used as an attempt to develop the learning materials in the intellectual skill, psychomotoric and verbal information domains so that it is very appropriate to develop the materials of Entrepreneur subject.

This research employs the approach of the developing research adapted from the opinion of Dick and Carey (1990) consisting of five stages, namely (1) determine lesson which is going to develop, (2) identify syllabus of lesson which is going to develop, (3) develop portfolio-based entrepreneurship learning design, (4) develop a topic in the display of portfolio-based learning, and (5) try the product of portfolio-based entrepreneurship learning design

\subsection{The Development Method of Learning Management System}

Learning Management System (LMS) is employ to learn electronic based automatically and virtually. While, many learning development models at the stage on student involevement and give channce for student to explore knowledge. The model shows a concept describing the real condition. Briggs (1978) stated that a model is a series of consecutive procedures to materialize a process. Based on both opinions, it can be concluded that the learning development model is a series of procedures consecutively done to develop the learning system.

This development should cover the structure of clear subject content and meet the applicable criteria for the learning development. It is in line with Mustaji's opinion (2000) stating that the advantages of the learning tool product with the developed constructivistic approach will gain the following: a) Considering the differences/variations of learning styles, the range of attention-interest-preference, memory, early competence, individual intelligence of the students, b) Considering that gifted students tend to have a strong curiosity about many things, have initiatives and competence to study independently, think critically-flexibly-productively, c) Considering that students have social aspects and gifted students should be able to learn together with other students, d) Students are provided with freedom atmosphere to have self-control, and e) Applying the individualized instruction, a learning activity that refers to AECT (1996) consisting of basic elements: choice of various forms of learning, choice of learning material, choice of learning location, flexible time arrangement, considering the early competence of the learners and learner evaluation with various forms and in a flexible schedule.

\section{RESEACH METHOD}

\subsection{Development Model}

The development model of this Entrepreneurship learning adopts the learning design model by Dick and Carey (1990), consisting of the following steps: (a) knowing the learning objective, (b) making 
the learning analysis, (c) knowing the input attitude and the student characteristics, (d) formulating the performance objective, (e) developing the pints of guideline reference test, (f) developing the learning strategy, (g) developing and selecting the learning material, (h) designing and doing formative evaluation, and (i) improving or revising the learning.

\subsection{The Procedures of Learning Management System-Based Entrepreneurship Learning Development}

The Learning Management System--based Entrepreneurship learning design above consists of five phases of development procedures. The First Phase is determining the subject to develop. The Second Phase is identifying the syllabus of the subject to develop. The Third Phase is the development phase of the Learning Management System--based Entrepreneurship learning, consisting of seven steps, namely: 1) analyzing the learning need, 2) identifying the general objective of learning, 3) analyzing and identifying the input attitude and student characteristics, 4) formulating the specific learning objective, 5) developing the learning material, 6) determining the steps and strategies of learning to follow, 7) determining the tool of process evaluation and learning outcome. The Fourth phase is developing topics into the presentation of the Learning Management System-based Entrepreneurship learning. The Fifth phase is the try-out phase of the Learning Management System--based Entrepreneurship learning design product, consisting of the learning model expert, field expert and learning technological expert review.

\subsection{The Product Try-Out}

\subsubsection{Population and Sample of Try Out}

\section{1.a. Research Population}

The population as the research subjects are the students of of State Polytechnic of Malang 600 students and 240 lecturers, at 10 departements of State Polytechnic of Malang.

\section{1.b. Research Sample}

The sampling methode for the product tryout is simple random sampling method by taking 3 subjects expert in entrepreneur, 1 learning expert and 1 learning technological expert.

\subsubsection{Tryout Design}

The steps of the product tryout of this Learning Management System-based Entrepreneurship learning development are as follows:

\subsubsection{Development Stages}

The Review of the Subject Expert, Learning Development/Design Expert and Computer Expert.

\subsubsection{Type of Data}

The data required in this research can be categorized as follows:

\section{a. Primary Data}

This study tries to collect the primary data from the subject expert (lecturer), learning media expert and design expert and students in the forms of opinions, suggestions and discussions.

\section{b. Secondary Data}

The secondary data related to this research is lesson plans, syllabus, and Entrepreneurship lecturers' names obtained through documentation and observations at State Polytechnic of Malang.

\subsubsection{Data Collection Instrument}

The instruments used to collect data are as follows:

a. Questionnaires, used to collect the following data:

The reviews of the subject expert (lecturer), media expert and learning design expert This measurement should meet four conditions, namely, the expert's approval, comprehension on the general instructions, being valid and reliable (Cronbach, 1980; Saukah, 2004).

b. Documentation, used for collecting data on lesson plans, syllabus, and names, Entrepreneurship lecturers' names 
c. Observation, used for collecting the data on the Entrepreneurship learning method available at the State Polytechnic of Malang.

d. Discussions with the subject experts (lecturers), the learning media experts, learning design experts, and students. They are used for collecting data for revisions and validation of the teaching materials, lesson plans, syllabus, learning method and evaluation system products (empiric) and constructivistic learning model.

e. The consultation with the subject experts (lecturers), learning media experts, and learning design experts that are used to collect data for revisions and validation of the teaching materials, lesson plans, syllabus, learning method and evaluation system products (empiric) and constructivistic learning model.

\subsubsection{Data Analysis Technique}

The data analysis used is as follows:

\section{a. Content Analysis}

This analysis is used for processing data from the interview and discussion with the experts, lecturers, and students and individual and small group tryout results. The content analysis is done by classifying information from qualitative data of input, opinion, criticism and suggestions for improvement in the questionnaire. The analysis results is used as the basis to revise the teaching material product.

\section{b. Descriptive Analysis}

\section{The Quality of Teaching Product}

This analysis is used for finding out the responses of the subject experts (lecturers), learning media experts, learning design experts and students on the quality of Learning Management System-based Entrepreneurship learning model. The response score can be mathematically formulated as follows:

$\Sigma$ (Response $\mathrm{x}$ weight of each option)

Percentage $=$ -

given:

$\mathrm{n}$ is the number of statements.

$81-100 \%$ : very good/interesting/suitable

$66-80 \%$ : good/interesting/suitable

$56-65 \%$ : not good/interesting/suitable

0 - 55\% : very bad/very not interesting/very not suitable

\section{RESUlt AND DisCUSS}

\subsection{Tryout Data Presentation}

\section{a. Result Data of Need Analysis (Needs Assessment)}

The need analysis data (Needs assessment) is obtained by collecting the questionnaires distributed to 3 subject lecturers of State Polytechnic of Malang. The question item on the need analysis covers : (1) Respondents' interest on the computer software in general, (2) Needs of Entrepreneurship Subject Development to develop based on the Learning Management System and to be used as the learning resources for the students of State Polytechnic of Malang, (3) The utilization of the Learning Managemenr System-based Entrepreneurship learning method, (4) The appropriateness of the design content in the Entrepreneurship subjects, and (5) the topics necessary and appropriate to develop.

\section{b. The Data of Review Results of Subject Experts, Learning Design Experts, and Computer Experts}

Findings show that the product of Learning Management System (LMS)-based entrepreneurship learning model is good. It means that product of LMS-based entrepreneurship learning model is valid to use in the learning process of entrepreneurship lesson at State Polytechnic of Malang. It is based on the try out results of its learning model development referred to Dick \& Carey (1971) and Kusumo \& Willis, with 6 indicators, namely (1) Learning Management System (LMS)-based entrepreneurship 
learning activity is interesting which is shown by the score of try out of $84.15 \%$, (2) Learning Management System (LMS)-based entrepreneurship learning model enables students to get better knowledge more about materials which are taught which is shown by the score of $78.36 \%$, (3) relationship between objectives of learning and materials taught in Learning Management System (LMS)-based entrepreneurship learning model is relevant which is shown by the score of $78.6 \%$, (4) test items can be used to measure the performance stated in the objective that stated in the achievement score of students' entrepreneurship attitude which is 3.6202 and score of students' entrepreneurship competence score which is 3.5238, (5) Learning Management System (LMS)-based entrepreneurship learning model is able to provide feedback, either for teachers or students, toward the process and results of students' learning which is shown by the score of $79.28 \%$, (6) Learning Management System (LMS)-based entrepreneurship learning model enables the improvement of satisfied materials and teaching which is shown by the score of $79.10 \%$.

\subsection{Discussion}

The development of Learning Management System (LMS)-based Entrepreneurship learning method in fact can help achieve the academic competence and motoric skill in Entrepreneurship. Theoretically, the academic achievement is possible from the result of the motivational effect leading to the improved attention and the intensity of the students' involvement in the learning process period using their conceptual knowledge so that it broadens and deepens (Waras, 2003). Besides, the constructivisticism-based learning (project) bases on the constructivistic perspective, where learning is not purely stimulus-response phenomenon as the perception of the behaviorists. Then the project assignment selected and determinded by the students is likely based on the conceptual knowledge they have had. In this context, the real activity done in the constructivisticism provides a learning experience that helps the reflection/abstraction and put the real life activities close to the underlying conceptual knowledge so that the academic knowledge develops more widely and deeply.

The advantages of Learning Management System (LMS) learning can also explained from the Constructive Learning theory. Simmons (1996) states that the memory representation is divided into three, namely semantic, episodic, and action representations. The semantic representation refers tot the concepts and princliples of a discipline with the accompanying characteristics. The episodic representation is based on the affective and personal experiences, while the action representation refers to the things done with the semantic and episodic information, for example, the settlement of a certain problem with certain knowledge. Thus, Learning Management System (LMS)based learning has more opportunities to develop the students' efforts to build the complex and rich memory representation and develop a strong relationship between semantic, episodic and action knowledge. This finding is line with the researches done by some researchers: Wataon, Prieto \& Dillon (1995), concluding that the concept comprehension on the discussion of the students learning through constructivisticism is better than those wo learn traditionally. Spinger, Sanne \& Donovan (1999) and Johson, Johnson \& Stanne (2000) studied some subjects, concluding that the learning collaboratively in small groups in constructivisticism with projects may improve the academic competence. Bragg \& Reger IV (2000) conclude that the integration of the academic and technical (vocational) learning may improve the academic and technical competences. Maskan \& Utomo (2009) concludes that the learning management system-based learning improves soft skill competence. While Maskan, Hadi and Aji (2010) points out that the psicomotoric, especially in e-learning competence (concept and principle comprehension) of student business administration following classes based on Web Modular is higher that Web Modular method.

But the improvement of the motoric competence from the theoretical perspective can be explained with the Motoric Learning theory on the "development rate" of the motoric competence (Schmidt, 1988) stating that it covers: 1) learning the technical (motoric) operation competence is a process of capacity achievement to perform; 2) Learning the technical operation competence is a result of practice/experience; and 3) The process results in the relatively permanent competence change. Thus, this finding is in line with the research done by Knoll (2002) stating that the constructivisticism-based learning (project) improve the academic and technical competences. Santiyasa (2004) found a difference of concept comprehension between the students learning with the setting of Group Investigation (GI) cooperative learning and Student Team-Achievement Division (STAD). Thomas (2000) \& Bragg \& Reger IV state that the technical competence improves together with the academic competence from the learning that integrates the academic and vocational aspects. Atio and Hansen 
(2002) concluded that the constructivisticism-based learning (project) that integrates the academic and occupational domains will excel in the technical thinking achievement than that of the technical motoric competence.

\section{CONCLUSION AND IMPLiCATION}

\subsection{Conclusion}

The product of Learning Management System (LMS)-based entrepreneurship learning model is good. It means that product of LMS-based entrepreneurship learning model is valid to use in the learning process of entrepreneurship lesson at State Polytechnic of Malang

\subsection{Implication}

Based on findings, the researcher suggests several recommendations so that the implementation of Learning Management System (LMS)-based entrepreneurship learning model may achieve optimum results, which are (1) teachers who are teaching lesson of entrepreneurship should be given provision about Learning Management System (LMS)-based entrepreneurship learning model, (2) For further development, this entrepreneurship learning model can be in the form of e-book based on internet and to validate this entrepreneurship learning model, it can be applied in other lessons.

\section{REFERENCES}

Adri, Muhammad, 2008, Pengembangan Model Belajar Jarak Jauh FT UNP dengan P4TK Medan dalam Rangka Perluasan Kesempatan Belajar, Komunitas e-learning Ilmu Komputer.com

Anwas, Oons, 2003, Definition of Educaional Technology, Association for Educational Adcroft,

Andy; Willis, Robert \& Dhaliwal, 2004, Missing Point? Management Education and Entrepreneur Ship, Management Decision, Vol. 42, No. 34, pp. $521-530$.

Aji, Deddy Kusbianto Purwoko, 2007, Analisa Kesiapan Adopsi Pembelajaran Elekronik di Politeknik Negeri Malang, Politeknik Negeri Malang.

Ary, D., Lucy C.J. \& Asghar R., 2002, Introduction to Research in Education, Belmont Wadsworth Thomson Learning.Communication and Technology, Washington, D.C.

Anderson, T. (1996) What in the world is Constructivism. Learning.March/April, p.48-51

Burke, John, W, 1995. Competency Based Educational and Training. New York: The Palmer Prest.

Cronbach, Lee. J., 1980, Essential of Psychological Testing, New York: Harper \& Row Publisher

Dick, W, L. Carey \& J.O. Carey, 2001, The Systematic Design of Instruction, 5th edition, New York: Harper Collin Publisher.

Hadi, Soetrisno, 2001, Statistik, Jilid 2, Andi Ofset, Yogyakarta

Harmanto, 2002, Pengembangan Pembelajaran Mata Kuliah Metodologi penelitian dengan Word Wide WEB di STIKOM Surabaya, Tesis, Program Pascasarjana Universitas Negeri Malang.

Hidayat, W., dan Fauzie, D., 2003, Pengalaman Menyelenggarakan School of Internet (SDI): Makalah dalam Workshop E-Learning di Perguruan Tinggi, ITB, Bandung

Nuraini, Nuning, 2003, Modul Multi Media Sebagai Salah Satu Sarana Peningkatan Motivasi Mahasiswa dalam Mempelajari Kalkulus, Makalah Seminar e-Learning, ITB Bandung.

Maskan, Mohammad \& Utomo, Heru, Pengembangan Model Pembelajaran E-Commerce Berbasis Internat dan Intranet di Jurusan Administrasi Niaga Politeknik Negeri Malang, 2009, Penelitian Hibah Bersaing, DP2M Dikti, Jakarta.

Maskan, Mohammad, Hadi, Musthofa \& Aji, Dedi Purwoko, Pengembangan Model Pembelajaran Pemasaran Internasional Berbasis Web Modular Berbantuan Intarnat dan Internet di Jurusan Administrasi Niaga Politeknik Negeri Malang, 2010, Penelitian Hibah Bersaing, DP2M Dikti, Jakarta.

Oetomo, Budi S. Dharma, 2002, e-Education: Konsep, Teknologi dan Aplikasi Internet Pendidikan, Andi Ofset, Yogyakarta

Patmanthara, Syaad, 2004, Pembelajaran Berbantuan Komputer Sebagai Manfaat Media Pembelajaran, Jurnal Teknologi Elektro dan Kejuruan, Oktober, 2004

Pancariana, Firman, 2005, Pengembangan Bahan Ajar Tekstual dan Digital pada Pembelajaran Aplikasi Komputer di Perguruan Tinggi, Tesis, Program Pascasarjana Universitas Negeri Malang. 
Model Development of Integrated Entrepreneurship Learning with based Internet/Intranet Learning Management System Applied at Malang State Polytechnic

Pavlik, John V., 1996, New Media Technology: Culture and Commercial Perspectives, Singapore: Ally and Bacon

Pramono, Y.G. Harto, 2002, Pengembangan Pembelajaran Berbantuan Komputer dalam Pokok Bahasan Present Tense Mata Kuliah Bahasa Inggris Program Studi Bahasa Inggris FKIP Katolik Widya Mandala Surabaya, Tesis, Program Pascasarjana Universitas Negeri Malang.

Purbo, Onno W., 2002, Teknologi e-Learning Berbasis PHP dan MySQL: Merencanakan dan Mengimplementasikan Sistem e-Learning, Jakarta: Gramedia.

Raharjo, Budi, 2001, Pergolakan Informasi di Indonesia akan Siaran?, Artikel Majalah Tempo, Jakarta: November 2001.

Saepudin, Asep, 2003, Penerapan Teknologi Informasi dalam Pendidikan Masyarakat, Journal Tekno, Pustekom.

Soekartawi, 2003, Prinsip Dasar E-Learning: Teori dan Aplikasinya di Indonesia, Jurnal Teknodik, Oktober 2003

Soekartawi, Soehardjono, Hartono dan Ansyarullah, 1999, Meningkatkan Instructional Design untuk Meningkatkan Kualitas Belajar-Mengajar, Grafindo Persada, Jakarta

Syakur, Abdus, 2006, Pengembangan Bahan Ajar Digital Mata Kuliah Aplikasi Komputer di STAIN Pamekasan, Tesis, Program Pascasarjana Universitas Negeri Malang.

Zahorik, John A. 1995. Constructivist Teaching, Bloomington, Indiana: Phi Delta Kappa Educational Foundation. 